\title{
27
}

\section{Scaling criminology: From street violence to atrocity crimes}

\author{
Susanne Karstedt ${ }^{1}$
}

\section{Criminology and regulation: Adopting principles}

In 2000, John Braithwaite argued for the 'transformation of criminology' and even for its abandonment as a discipline in favour of all-encompassing 'studies of regulation' (2000: 223). As he noted then, this was not to happen in the near future, and, indeed, it did not happen. What happened, and what he had started a decade earlier, was an invasion of regulation theory, concepts and ideas into criminology, which, in many and prolific ways, changed how criminologists think. Most influential among these were the principles and practices of restorative justice, which became the most successful criminal justice innovation worldwide since the adoption of the panopticon prison in the nineteenth century (Parmentier et al. 2011).

1 I owe immense gratitude to the Regulatory Institutions Network (RegNet) as an institution, and to all those who made it one of the most wonderful intellectual networks and inspiring environments I have ever known. In particular, I wish to thank John and Valerie Braithwaite, Hilary Charlesworth, Peter Drahos and Peter Grabosky for support, guidance and inspiration. I would also like to thank the wonderful research students whom I taught in 2013 and 2014. 
However, there are more lessons to be learned for criminology and more conceptual tools to be imported from the regulatory framework. These are foundational principles rather than developed practices. This chapter will explore the potential of the basic principles of regulation theory and concepts for criminology, and will use the exemplary case of extreme and high-level violence. It will focus on three principles that I identify as most important in this area: context independency, scale independency and sequencing.

These three principles are representative of the definition of (responsive) regulation as 'a general theory of how to steer the flow of events' (Braithwaite 2014: 432; Parker and Braithwaite 2003). This certainly is in stark contrast with traditional and, in particular, aetiological, criminology with its focus on the offender and controlling them. It has, however, much in common with more recent theoretical and conceptual developments in criminology such as routine activity theory and situational and environmental crime prevention; these are frameworks that focus on the crime incident rather than on the individuals involved. In this way, criminology and regulatory concepts share a common perspective on the dynamics of events, the role of actors within these and their decision-making processes (for example, Leclerc and Wortley 2014). The common perspective includes the principles of intervening in the flows of events. Consequently, both criminological and regulatory perspectives address proximate factors rather than distal or root causes, and promote interventions that are based on the former rather than on the latter.

Context and scale independency imply that we can move: between different types of the same event, for example, violence in pub brawls and violence between ethnic groups; between different types of events, for example, tax evasion and violence; between the local and the global and between micro and macro-contexts; or between different types of actors such as corporations and militias. Sequencing is a principle that originates from the focus on the 'flows of events' and implies a move along with the flow, following its original dynamics and changing its trajectory at different stages in different ways.

The overall aim of this chapter is to demonstrate how these principles can inform the use of criminological knowledge and research for the prevention of incidents of mass violence and atrocity crimes, as well as for interventions when they evolve. The plan of the chapter is, first, to define the set of circumstances in which contemporary mass violence 
takes place. The next sections will then explore the ways in which criminological knowledge and research evidence can be gauged for violence prevention and intervention in such contexts. I move on to ways of using knowledge and evidence from such large-scale violence to the smaller scales of street crime and gang networks. This is a process of both scaling up and scaling down, of moving from micro to macro-contexts and vice versa.

\section{Contemporary landscapes of mass violence and atrocity crimes}

The term 'atrocity crime' as used here is now widely adopted for massive violence committed by state and non-state actors. It includes the international crimes of genocide, war crimes and crimes against humanity, such as torture or forced disappearance, as well as ethnic cleansing (Scheffer 2006; Karstedt 2013a; UN 2014). Contemporary contexts of mass violence evolve in a landscape of long-term and multifaceted conflicts, extreme violence and state fragility (for an overview, see Karstedt 2013a). The majority of mass killings since World War II have been part of civil wars and ethnic conflicts (Kalyvas and Balcells 2010). These conflicts typically occur below the level of the nation-state and independent of its boundaries.

These are conditions and environments that Christian Gerlach (2010) describes as 'extremely violent societies'. This defines a (temporary) condition of society where violence has become endemic and encompassing. First, violence becomes 'multipolar': different groups become victims of massive attacks of physical violence, including mass killings, systematic sexual violence and enforced displacement, and mass violence oscillates between these different forms of violence. Next, participation in these events spreads across the boundaries of different groups and, consequently, the lines between different types of involvement and non-involvement become blurred, as does the distinction between victim and perpetrator groups. Further, diverse groups of perpetrators participate for multiple and often changing reasons, ranging from domination or ethnic hatred to access to resources and criminal exploitation of the population through extortion and taxation. Groups include state government forces, paramilitary forces and militias, rebel forces and warlord groups-all of whom engage in complex and shifting alliances with each other or government forces. The conflict 
in the Great Lakes Region of Africa involving Rwanda, Burundi and the Democratic Republic of the Congo (DRC) is an exemplary case. Between the 1950s and the 1990s, Hutus and Tutsis changed place as victims and perpetrators more than once (Prunier 2009). The final crisis and mass atrocities in Darfur, Sudan, were the last in a series of conflicts that reached back across half a century and targeted different groups; they all included atrocities on a massive scale (Flint and de Waal 2008).

Atrocity crimes are increasingly committed by non-state organised actors such as paramilitary groups, who often are encouraged, empowered and guided by state actors such as the police or military or other powerful actors such as opposition leaders. These developments were first visible in Central and Latin America from the 1980s onwards (Guatemala, Colombia) (Rothenberg 2012), and then in Yugoslavia in the 1990s, Darfur (Hagan and Rymond-Richmond 2009), DRC (Autesserre 2010) and the Central African Republic. The engagement of state forces such as the military and the police in paramilitary action creates a situation where laws and restraint are easily and deliberately ignored; this is fertile ground for forced displacement, torture and widespread sexual violence, as, for example, in Guatemala (Rothenberg 2012). Such atrocities are often linked to other criminal activity, including weapon and drug trafficking or illegal natural resources exploitation.

We can track these developments in the declining incidents of mass atrocities and their death toll, as shown in Figure 27.1. There is a rapid decline after 1990 in the number of incidents, which mostly-with the exception of the Rwandan genocide-coincides with a substantive decrease of victims. With a considerable lag, campaigns of one-sided violence by state actors (police, military and paramilitary units organised by the state) against civilians - that is, noncombatants - as well as the number of victims started to decline in the second half of the 1990s; this mainly concerns atrocity crimes on a smaller scale (Human Security Report Project 2011; Sikkink 2011). However-and in line with the contextual patterns of extreme violence as described abovethe involvement of non-state actors such as militias, paramilitary defence groups, rebel groups and warlord armies has risen from a low 30 per cent in 1997 to more than 80 per cent of all conflicts globally in 2007 (Human Security Report Project 2011, 2013). Hence, they are increasingly responsible for the massive violence, atrocities and dispossession committed against populations, and for the 'horizontal violence', in contrast to state-led 'vertical' violence. 


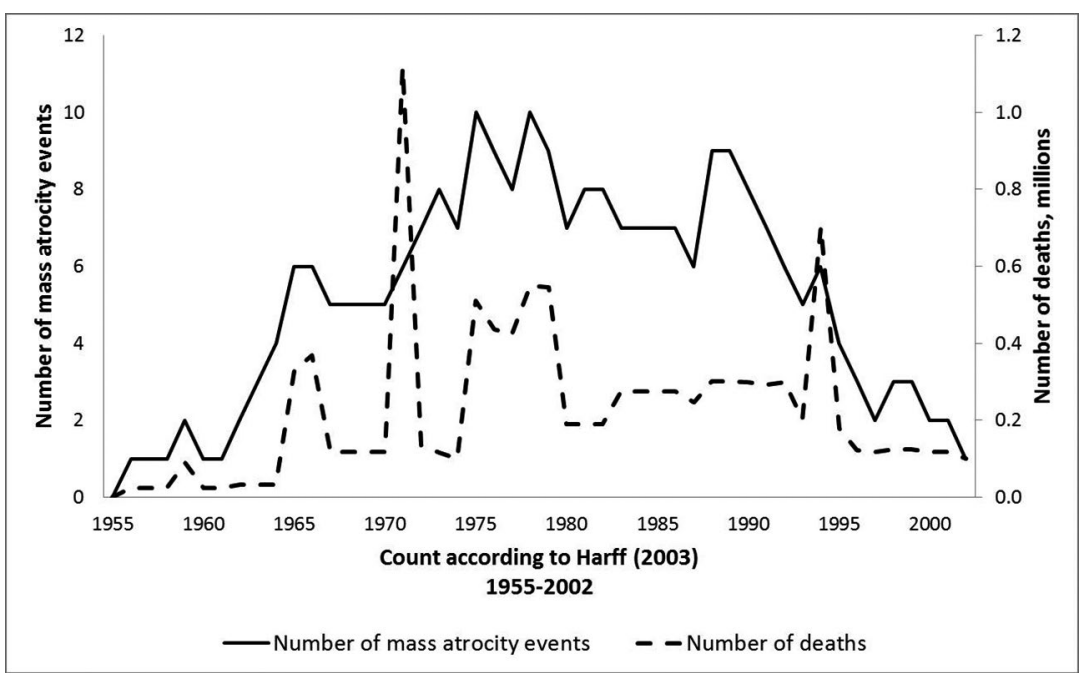

Figure 27.1 The global dynamics of violence, 1955-2002: Mass atrocities and deaths

Source: Author's work, adapted from Harff (2003).

These contextual patterns have been measured with a Violent Societies Index (VSI), which addresses the typical combination of different types of violence. It includes battle deaths, (repressive) state violence, terrorist attacks and interpersonal violence (homicide). ${ }^{2}$ Table 27.1 shows the top-20 'violent societies' across the 2000s, and demonstrates a number of distinctive features. First, most of these societies experienced mass atrocity events, either between 2000 and 2012 or previously. Second, those societies that had been among the most violent societies in the first half of the decade remained in this group in the second half until 2012. Extreme violence is entrenched and path-dependent; this applies equally when the most violent countries are tracked over a much longer period, from 1980 to 2009 (Karstedt 2012). State violence is most consistently correlated with all other types of violence, and it is a strong predictor for levels of other types of violence across both five-year and 10-year periods. In particular, where state violence had been high, homicide

2 For each of the types of violence, a scale from one to 10 was constructed from available data sources. The VSI covers the period since 1976; as homicide rates were not available for the whole period and for many of the countries, one version of the VSI (VSI30) includes only battle deaths, state violence and terrorist attacks. A second version, VSI40, includes homicides and covers the period since 1995. The VSI40 is used here. For details, see Karstedt (2012). 
levels tended to be high in the following years (Karstedt 2013b, 2014). ${ }^{3}$ State-led violence consistently seems to be most detrimental for the social and institutional fabric of societies, and its impact on societies is the most long-lasting. ${ }^{4}$

Table 27.1 Violent Societies Index: Top 20 countries, 2000-2012

\begin{tabular}{|c|c|c|c|c|}
\hline & \multicolumn{2}{|c|}{$2000-06$} & \multicolumn{2}{|c|}{ 2007-12 } \\
\hline Rank & Country & VSI & Country & VSI \\
\hline 1 & Colombia & 23.3 & Pakistan* $^{*}$ & 16.1 \\
\hline 2 & Russia* & 15.1 & Colombia & 14.8 \\
\hline 3 & India* & 13.6 & Honduras & 13.3 \\
\hline 4 & $\mid$ srael* & 13.0 & Jamaica & 12.6 \\
\hline 5 & $\mathrm{Nepal}^{*}$ & 12.8 & India* & 12.3 \\
\hline 6 & Algeria* $^{*}$ & 12.8 & El Salvador* & 11.4 \\
\hline 7 & El Salvador & 11.7 & Russia* & 11.1 \\
\hline 8 & Jamaica & 11.3 & Philippines* & 10.3 \\
\hline 9 & South Africa* & 11.2 & Venezuela & 10.3 \\
\hline 10 & Philippines $^{\star}$ & 11.1 & Israel* $^{*}$ & 10.2 \\
\hline 11 & Uganda* & 11.0 & Syria* $^{*}$ & 9.6 \\
\hline 12 & Brazil & 10.7 & Brazil & 9.6 \\
\hline 13 & Honduras & 10.5 & South Africa* & 9.5 \\
\hline 14 & Indonesia* & 9.6 & Thailand & 9.5 \\
\hline 15 & Pakistan* & 9.3 & Guatemala* $^{*}$ & 9.1 \\
\hline 16 & Venezuela & 9.0 & Yemen* & 9.1 \\
\hline 17 & Guatemala* & 8.8 & Mexico & 8.7 \\
\hline 18 & Haiti & 8.3 & Dominican Republic & 8.6 \\
\hline 19 & China* $^{*}$ & 7.9 & Uganda* & 8.1 \\
\hline 20 & Thailand & 7.8 & China* & 7.6 \\
\hline
\end{tabular}

${ }^{*}$ Previous mass atrocity

Note: Countries in bold were included in the top-20 countries, 2000-06.

Sources: Author's work based on Violent Societies Index, VSI40, including homicide rates; see Karstedt (2012: notes 4, 5).

3 The correlations across countries were calculated for selected years in each decade (Karstedt 2012).

4 See Karstedt (2015) for the impact of state violence on trust in police and justice in transitional and post-conflict societies. 
At the micro-level of local communities and individual involvement, clearcut divisions into perpetrators, bystanders, collaborators and victims are increasingly blurred. Here, local dynamics and family and friendship bonds play a role, as Fujii (2009) has shown for the recruitment process into violent groups and participation in violence. Looting, arson and damage to property, as well as assaults on the population and sexual assaults can be immediate precursors of massive violence, but often are not taken further than this. These types of violent action are used to threaten and intimidate the population and enforce displacement where resources are exploited. These are conditions where organised criminal groups become involved. Exemplary for these changes were two militia leaders who operated in the north of the DRC, Mai Mai Checka and Bosco Ntaganda. Both led militias and rebel groups who were involved in illegal resource exploitation and forms of organised crime, and committed atrocity crimes including sexual violence and slavery. Their forces and groups committed mass atrocities serious enough for the International Criminal Court (ICC) to issue arrest warrants and for the United Nations Security Council (UNSC) to send an intervention force with an explicit mandate to use force (Braithwaite 2013; UN News Centre 2013).

These types of violence and the actors involved have much more in common with violence in the streets of Baltimore and Rio de Janeiro, and with gang violence, than the model of state-led and hate-induced atrocity crime would suggest (Alvarez 1999). Pre-existing factors such as ethnic tensions and hatred, or discrimination per se, are not sufficient for mass atrocities to happen, nor are these root causes easily addressed. Such types of violence and their context lend themselves to policing and justice strategies rather than military interventions (Hills 2015: 1). It is from this vantage point that criminological knowledge and research evidence can contribute to prevention and intervention.

\section{Scaling up: From street crime to atrocity crimes}

Regulation theory includes deterrence as a regulatory strategy; however, deterrence is used in a sequenced and 'dynamic' approach and as a 'tough deterrent peak' that 'drives action down to the dialogic base of the pyramid' (Braithwaite 2014: 433). Equally, action can be driven up to the top of the sanction pyramid, if dialogue fails at its broad base. 
Where domestic and international communities intervene in contexts of extreme violence, the threat and the use of force against (potential) perpetrators as well as the threat of legal prosecution and sanctions combine at the top of the sanction pyramid. The former is a matter of control and the use of technology and manpower; the latter resides in the credibility of international and domestic criminal justice to bring perpetrators to justice. This implies both a dynamic and a sequenced use of deterrence rather than static and 'passive deterrence' (Braithwaite 2014: 433).

There is presently little evidence that international prosecution and sentencing can act as such a deterrent at the peak of the regulatory pyramid and bolster dialogue at its base. Akhavan (2009) provides anecdotal evidence from Uganda and Sudan that leaders of militias and armed groups feared defection as a consequence of arrest warrants issued by the ICC. Sikkink (2011) and Olsen et al. (2010) conclude from systematic research that criminal justice prosecution works as a deterrent only in combination with other truth and reconciliation measures, which, however, are located more at the dialogic base of the sanction pyramid than at its top.

Criminological research provides systematic evidence that deterrent effects seemingly reside in policing, police presence and certainty of being arrested and prosecuted rather than in the threat of long prison sentences (Durlauf and Nagin 2011). Recently, a set of newly implemented and evaluated policing practices termed 'lever-pulling policing' has shown promising results in terms of reducing violence, mainly related to drug markets, gun use and gang activity (Braga and Weisburd 2012; Corsaro et al. 2012). These practices are based on the principles of 'dynamic concentration of deterrence' (Kleiman 2009; Kennedy 2008), which move deterrence from a static and passive principle to a sequenced and dialogical one. They are based on the characteristics that most violent settings share. Both street crime and situations of extreme violence are highly concentrated in 'hotspots' (Raleigh and Hegre 2009). Raleigh et al. (2010) found that entrenched and repetitive violence was, on average, concentrated in 15 per cent of a country's territory. Spatial analyses of extreme violence and mass atrocities thus confirm that they are as highly concentrated in hotspots as violence and crime generally, and that a comparably small number of communities suffer extreme victimisation while many others are spared (Hagan et al. 2005; Rothenberg 2012; Braithwaite 2012). However, concentrated violence on the street level and in violent conflicts is simultaneously contagious, and spreads to 
proximate areas if conducive conditions prevail there (for US street crime, see Mears and Bahti 2006; for conflicts and violence, see Buhaug and Gleditsch 2008). With these common characteristics, violence is an exemplary case for exploring scale and context independency.

The strategies of lever-pulling policing and 'dynamic deterrence' are based on four principles: selective focusing; communication and dialogue; future orientation; and a broad range and escalation of intervening actions (Kennedy 2008; Kleiman 2009). First, the police focus resources on selected and known offenders, which often are leaders of networks and gangs (Bichler and Malm 2015). Second, police engage in directed and targeted communication with this group. This involves identifying networks, leaders and followers, and communicating the deterrent threat and its potential escalation to this group. Third, and importantly, the threat does not address past crimes but is directed at future criminal activity of this group and its leaders. Finally, the group will be informed as part of the communication strategy that the police will use all resources and mechanisms available in case of noncompliance ('pulling all levers'). 'Dynamic concentration of deterrence' refers to the practice of successive targeting of perpetrator groups: if the deterrent threat fails with the selected leadership group of perpetrators, the resources are deployed towards the next level, and the larger group. Thus, ordinary members are becoming involved in putting pressure on their leaders to comply (Kleiman 2009).

In a number of programs, the deterrent threat has been part of a broader offer for routes out of violent action. In such programs, the deterrent threat was communicated in meetings, which included community members, as well as social and welfare services; it was thus complemented by offers of support and positive incentives for compliance. When applied to spatial clusters of criminal activity (hotspots), the principle of concentration of deterrence has been successful: focused, intermittent and non-permanent deployment of police to the small number of hotspots significantly reduced crime and violence there, and often in adjacent areas, resulting in a substantive reduction of the overall rate of crime and violence (Weisburd et al. 2011).

In which ways can these principles be scaled up from street crime to high-risk conflict zones? Violence in these contexts is mostly violence against all members of a group and, as such, is indiscriminately deployed. Can such indiscriminate violence be met by programs of selective deterrence? Krain (2005) shows that interventions in such contexts 
that directly challenge perpetrators and restrain and disarm them are effective in slowing and stopping mass violence. The concentration of resources and targets makes these practices particularly adaptive to an environment where control is contested, where the capacity of protective forces is low and where criminal justice agencies are institutionally weak. Public commitment to targeted and intensive enforcement for future crimes and not crimes in the past thus can support the monitoring of specific types of violence (for example, sexual violence) or of a group of known and identified perpetrators. Concentration, selectivity and direct communication may address the major problem of credibility in creating security and deterring violent action. These strategies might also generate safe zones, as targeted groups take refuge in communities with known clusters of (law) enforcement and deterrent action (Czaika and Kis-Katos 2009).

Strategies of concentrated dynamic deterrence address networks of perpetrators. Atrocity crimes are collective action and violence, most often committed by groups who are organised, trained and part of a command chain; most of the violence, therefore, is structured in terms of timing, location and use of weapons (Verwimp 2006). The 'webs of violence' through which perpetrators transmit threats and fear, and social networks and neighbourhood ties that facilitate recruitment and involvement (Fujii 2009), provide channels for targeted messages of deterrent threats. Local and regional leaders at the lower levels might be more susceptible to both threats of deterrence and positive incentives for compliance than the highest level of leadership (Braithwaite 2013). As successful gun-control programs in violence and gang-ridden cities in the United States demonstrate, concentrated deterrence supplemented by incentives for handing in guns can significantly reduce violence (Kleiman 2009; Kennedy 2008). Peacebuilding programs that included arms control, or flanked concentrated deterrence with offers of welfare and support, have been successfully implemented in conflict zones (Braithwaite et al. 2011).

The practices of dynamic deterrence are genuinely embedded in local contexts. Consequently, those who use them need to have at least sufficient knowledge of local actors, conflicts and potential allies and opponents; otherwise, these strategies fire back and fuel conflict and violence (Autesserre 2012). They can be used by a broad range of actors regardless of whether their task is protection of victims or prosecution of perpetrators: local authorities who try to build up resistance and defence against atrocity crimes, national law enforcement and enforcement of 
international criminal law. Concentrated deterrence practices can be used in establishing safe zones for victims, preventing recruitment into violent groups and activities, restraining leaders of collective violence or encouraging defection of subordinates. They meet their greatest challenge when confronting extremely ruthless opponents, the governments and their military and security forces-all strictly organised and hierarchical forces. Here, the limits of regulatory theory and of the role it assigns to dynamic deterrence become obvious (Braithwaite 2014).

\section{Scaling down: Peacebuilding in states and gang-ridden communities}

Scaling down implies that strategies for the 'regulation of states' can be applied to the 'regulation by states' (Braithwaite 2014: 452), and to their domestic crime and justice problems. At the level of states and the international system, the dynamic escalation of deterrent and forceful action is common. It is based on prioritising dialogue and communication before escalating. Most recently, it has been flanked by internationally led peacebuilding programs in conflict-ridden states and regions that encompass both peace settlements and transitional justice. Increasingly, peace and justice are seen not as antagonistic, but as parts of a framework of sequencing 'truth, reconciliation and justice' (Braithwaite and Nickson 2012). Can we scale down from evidence on peace negotiations, peacebuilding and settlement to violence reduction and prevention in urban neighbourhoods?

The answer is: yes, we can. The exponentially growing number of peacekeeping and peacebuilding missions since the end of the Cold War provides a solid database for case and quantitative studies (Human Security Report Project 2011: Overview). Most important for scaling down are three results of this research. First, mediation-whether resulting in ceasefires or full or partial settlements-is successful in more than half of the cases, and only 4 per cent fail completely (Regan et al. 2009). This is confirmed for regional conflicts in South-East Asia and Oceania, with a strong positive relationship between mediation and reduction of violence (Möller et al. 2011). Second, interventions, peace operations and the presence of a peacekeeping mission significantly reduce the risk of recurrence of violence (Doyle and Sambanis 2006; Fortna 2008). Such forces are particularly important to provide security for groups in disarmament and demobilisation programs (Human 
Security Report Project 2011: 72-3). Third, peace agreements are successful in terminating violence in two-thirds of the cases, while violence recurs and is resumed within a five-year period in a minority of 32 per cent of the cases (Human Security Report Project 2013: 175). However, if violence is resumed, it is at a reduced level of overall violence (Human Security Report Project 2013: 176).

For securing and policing gang-ridden neighbourhoods, two conclusions can be drawn. Mediation is nearly always the better option to end violence, which should not only involve police forces but also follow models from peacekeeping by engaging 'groups of friends' from local neighbourhoods, or even other cities. Further, where violence is entrenched and at high levels, efforts at communication, dialogue and mediation need to be repeated as often as a deterrent approach. A singleshot intervention does not seem sufficient and, in a substantive number of cases, violence will be resumed; however, returning to previous levels will be a rather rare outcome. Successful mediation is mostly based on numerous failed attempts. ${ }^{5}$

Scaling down does not necessarily imply the transfer of these models to more stable environments, better functioning contexts or established and democratic criminal justice systems. Gang-ridden neighbourhoods in Central American cities neither have the local capacity for nor can they rely on a functioning system of criminal justice or on noncorrupt police forces. Doyle and Sambanis (2006) caution that the mechanisms of peacebuilding probably will not be successful where local institutional and economic capacity are at a low level or non-existent. It is therefore important in scaling down to know the local context and to engage local actors in building capacity. Violent actors often include members of the police forces and they are part of the violence problem rather than contributing to its solution.

\section{Towards a criminology of multiple scales}

Moving the scale of criminology from small worlds to larger ones and back again has proven to be a productive strategy. It owes much to the links that have been established between criminology and regulatory studies, and, in particular, to three regulatory principles: context

5 Personal communication from John Braithwaite, based on data from the Peacekeeping Compared Project, June 2015. 
independency, scale independency and sequencing. All three principles encourage a focus on 'flows' and dynamics, and moving between scales. When moving up in scale, much can be learned from micro-contexts of networks, families and neighbourhoods for larger collectivities and extreme violence. When moving down in scale, much is to be gleaned from conflict and extremely violent societies for addressing the problems of gang and violence-ridden neighbourhoods. Scaling down from the international and state levels to the neighbourhood level and up again has the potential to provide fresh insights for both levels. Should we think of crime-ridden neighbourhoods as failing states? Failing states are like bad neighbours and peers: they export violence and are contagious (Karstedt 2013b).

I would therefore like to encourage a criminology of multiple scales. This will be a criminology that moves easily between the different scales, between the local neighbourhood and the global sphere, between gang networks in a local neighbourhood and the organised crime actor into which some states degenerate, or between local and global hotspots of violence (Braithwaite 2012; Karstedt 2013b). Moving our theories up and down the scale will provide fresh insights, and help to reshape and refine them (Braithwaite 2014). Moving evidence-led practices from the large to the small scale and vice versa will greatly enhance our repertoire of crime prevention. Thus, criminologists could profit from research on peacekeeping that finds that mediation seems to be the best option to end violence (Human Security Report Project 2013: 175). In return, criminologists could offer principles of hotspot policing to conflict and violence-ridden countries. In this endeavour, criminology will greatly profit from regulatory studies and theory.

\section{Further reading}

Chirot, D and McCauley, D 2010. Why Not Kill Them All? The Logic and Prevention of Mass Political Murder. 2nd edn. Princeton, NJ: Princeton University Press. doi.org/10.1515/9781400834853.

Haveman, R and Smeulers, A (eds) 2008. Supranational Criminology: Towards a Criminology of International Crimes. Antwerp: Intersentia.

Weisburd, D, Bernasco, W and Bruinsma, G (eds) 2008. Putting Crime in its Place: Units of Analysis in Geographic Criminology. New York: Springer. 


\section{References}

Akhavan, P 2009. 'Are international criminal tribunals a disincentive to peace? Reconciling judicial romanticism with political realism', Human Rights Quarterly 31(3): 624-54. doi.org/10.1353/hrq.0.0096.

Alvarez, JE 1999. 'Crimes of states/crimes of hate: Lessons from Rwanda', Yale Journal of International Law 24(2): 365-483.

Autesserre, S 2010. The Trouble with the Congo: Local Violence and the Failure of International Peacebuilding. Cambridge: Cambridge University Press. doi.org/10.1017/CBO9780511761034.

Autesserre, S 2012. 'Dangerous tales: Dominant narratives on the Congo and their unintended consequences', African Affairs 111(443): 202-22. doi.org/10.1093/afraf/adr080.

Bichler, G and Malm, A (eds) 2015. Disrupting Criminal Networks: Network Analysis in Crime Prevention. London: FirstForumPress.

Braga, AA and Weisburd, DL 2012. 'The effects of focused deterrence strategies on crime: A systematic review and meta-analysis of the empirical evidence', Journal of Research in Crime and Delinquency 49(3): 323-58. doi.org/10.1177/0022427811419368.

Braithwaite, J 2000. 'The new regulatory state and the transformation of criminology', British Journal of Criminology 40(2): 222-38. doi. org/10.1093/bjc/40.2.222.

Braithwaite, J 2012. 'Cascades of violence and a global criminology of place', Australian E' New Zealand Journal of Criminology 45(3): 299-315. /doi.org/10.1177/0004865812456857.

Braithwaite, J 2013. 'Relational republican regulation', Regulation \&o Governance 7(1): 124-44. doi.org/10.1111/rego.12004.

Braithwaite, J 2014. 'Limits on violence: Limits on responsive regulatory theory', Law \& Policy 36(4): 432-56. doi.org/10.1111/lapo.12026.

Braithwaite, J and Nickson, R 2012. 'Timing truth, reconciliation and justice after war', Obio State Journal on Dispute Resolution 27(3): 443-76. 
Braithwaite, J, Charlesworth, H, Reddy, P and Dunn, L 2011. Reconciliation and Architectures of Commitment: Sequencing Peace in Bougainville. Canberra: ANU E Press.

Buhaug, H and Gleditsch, KS 2008. 'Contagion or confusion? Why conflicts cluster in space', International Studies Quarterly 52(2): 215-33. doi.org/10.1111/j.1468-2478.2008.00499.x.

Corsaro, N, Hunt, ED, Hipple, NK and McGarrell, EF 2012. 'The impact of drug market pulling levers policing on neighborhood violence', Criminology E Public Policy 11(2):167-99. doi.org/10.1111/ j.1745-9133.2012.00798.x.

Czaika, M and Kis-Katos, K 2009. 'Civil conflict and displacement: Village-level determinants of forced migration in Aceh', Journal of Peace Research 46(3): 399-418. doi.org/10.1177/ 0022343309102659.

Doyle, MW and Sambanis, N 2006. Making War and Building Peace. Princeton, NJ: Oxford University Press.

Durlauf, SN and Nagin, DS 2011. 'Imprisonment and crime: Can both be reduced?', Criminology \& Public Policy 10(1): 13-54. doi.org/ 10.1111/j.1745-9133.2010.00680.x.

Flint, J and de Waal, A 2008. Darfur: A New History of a Long War. London: Zed Books.

Fortna, V 2008. Does Peacekeeping Work? Princeton, NJ: Princeton University Press.

Fujii, LA 2009. Killing Neighbors: Webs of Violence in Rwanda. Ithaca, NY: Cornell University Press.

Gerlach, C 2010. Extremely Violent Societies: Mass Violence in the Twentieth-Century World. Cambridge: Cambridge University Press. doi.org/10.1017/CBO9780511781254.

Hagan, J and Rymond-Richmond, W 2009. Darfur and the Crime of Genocide. Cambridge: Cambridge University Press.

Hagan, J, Rymond-Richmond, W and Parker, P 2005. 'The criminology of genocide: The death and rape of Darfur', Criminology 43(3): 525-62. doi.org/10.1111/j.00111348.2005.00016.x. 
Harff,B 2003.'No lessons learned from the Holocaust?', American Political Science Review 97(1): 57-73. doi.org/10.1017/S0003055403000522.

Hills, A 2015. 'International policing: The stabilisation unit's new clothes', Policing 9(3): 284-91. doi.org/10.1093/police/pau062.

Human Security Report Project 2011. Human Security Report 2009/2010: The Causes of Peace and the Shrinking Costs of War. New York: Oxford University Press. Available at: hsrgroup.org/docs/Publications/HSR 20092010/20092010HumanSecurityReport-CoverPage.pdf.

Human Security Report Project 2013. Human Security Report 2012. Sexual Violence, Education and War: Beyond the Mainstream Narrative. Vancouver: Human Security Press.

Kalyvas, SN and Balcells, L 2010. 'International system and technologies of rebellion: How the end of the Cold War shaped international conflict', American Political Science Review 104(3): 415-29. doi.org/ 10.1017/S0003055410000286.

Karstedt, S 2012. 'Extremely violent societies: Exploring the dynamics of violence and peace', European Journal of Criminology 9(5): 499513. doi.org/10.1177/1477370812454646.

Karstedt, S 2013a. 'Contextualizing mass atrocity crimes: Moving towards a relational approach', Annual Review of Law and Social Sciences 9: 383-404. doi.org/10.1146/annurev-lawsocsci-102612-134016.

Karstedt, S 2013b. Global hot spots of violence: Exploring the paradox of state strength and weakness, Annual Nigel Walker Lecture, Institute of Criminology, University of Cambridge, Cambridge, 13 June. Available at: youtube.com/watch?v=xGgMoV11jqE.

Karstedt, S 2014. Global hot spots of violence: How to focus intervention and prevention, Global Violence Reduction Conference, Violence Research Centre, University of Cambridge, Cambridge, 17-19 September. Available at: youtube.com/ watch?v=2Z_4NVGaq0o.

Karstedt, S 2015. 'Trust in transition: Legitimacy of criminal justice in transitional societies', in G Mesko and J Tankebe (eds), Trust and Legitimacy in Criminal Justice: European Perspectives. New York: Springer, pp. 3-32. doi.org/10.1007/978-3-319-09813-5_1. 
Kennedy, DM 2008. Deterrence and Crime Prevention: Reconsidering the Prospect of Sanction. New York: Routledge.

Kleiman, MAR 2009. When Brute Force Fails: How to Have Less Crime and Less Punishment. Princeton, NJ: Princeton University Press. doi.org/10.1515/9781400831265.

Krain, M 2005. 'International intervention and the severity of genocides and politicides', International Studies Quarterly 49(3): 363-87. doi.org/10.1111/j.1468-2478.2005.00369.x.

Leclerc, B and Wortley, R (eds) 2014. Cognition and Crime: Offender Decision Making and Script Analysis. London: Routledge.

Mears, DP and Bhati, AS 2006. 'No community is an island: The effects of resource deprivation on urban violence in spatially and socially proximate communities', Criminology 44(3): 509-48. doi.org/10.1111/j.1745-9125.2006.00056.x.

Möller, F,DeRouen, K, Bercovitch,J and Wallensteen, P 2011. 'The limits of peace: Third parties in civil wars in Southeast Asia, 1993-2004', in $\mathrm{J}$ Bercovitch and $\mathrm{K}$ DeRouen (eds), Unravelling Internal Conflicts in East Asia and the Pacific. Plymouth, UK: Lexington Books, pp. 47-68.

Olsen, T, Payne, LA and Reiter, AG 2010. Transitional Justice in Balance: Comparing Processes, Weighing Efficacy. Washington, DC: United States Institute of Peace Press.

Parker, C and Braithwaite, J 2003. 'Regulation', in P Cane and M Tushnet (eds), The Oxford Handbook of Legal Studies. Oxford: Oxford University Press, pp. 119-45.

Parmentier, S, Walgrave, L, Aertsen, I, Maesschalck, J and Paoli, L (eds) 2011. A Sparking Discipline: The Contribution of Criminology to Social Justice and Sustainable Dervelopment. Essays on the Occasion of the Honorary Doctorate for John Braithwaite. Leuven, Belgium: Leuven University Press.

Prunier, G 2009. Africa's World War: Congo, the Rwandan Genocide and the Making of a Continental Catastrophe. Oxford: Oxford University Press. 
Raleigh, C and Hegre, H 2009. 'Population size, concentration and civil war', Political Geography 28(2): 224-38. doi.org/10.1016/j. polgeo.2009.05.007.

Raleigh, C, Linke, A, Hegre, H and Karlsen, J 2010. 'Introducing the ACLED: An armed conflict location and event dataset-Special data feature', Journal of Peace Research 47(5): 651-60. doi.org/ 10.1177/0022343310378914.

Regan, PM, Frank, RW and Aydin, A 2009. 'Diplomatic interventions and civil war: A new dataset', Journal of Peace Research 46(1): 135-46. doi.org/10.1177/0022343308098408.

Rothenberg, D (ed.) 2012. Memory of Silence: The Guatemalan Truth Commission Report. New York: Palgrave Macmillan.

Scheffer, D 2006. 'Genocide and atrocity crimes', Genocide Studies and Prevention 1(3): 229-50. doi.org/10.3138/E832-0314-6712$60 \mathrm{H} 3$.

Sikkink, K 2011. The Justice Cascade: How Human Rights Prosecutions are Changing World Politics. New York: WW Norton \& Co.

United Nations (UN) 2014. Framework of Analysis for Atrocity Crimes: A Tool for Prevention. New York: UN Office on Genocide Prevention and the Responsibility to Protect. Available at: un.org/en/ preventgenocide/adviser/.

United Nations News Centre 2013. Security Council approves intervention force to target armed groups in DR Congo, News item, 28 March. New York: United Nations. Available at: un.org/apps/ news/story.asp?NewsID=44523\#.UWJ5w1eyI3Q.

Verwimp, P 2006. 'Machetes and firearms: The organization of massacres in Rwanda', Journal of Peace Research 43(1): 5-22. doi.org/ 10.1177/0022343306059576.

Weisburd, DL, Cody, T, Teichman, D, Gill, C and Vitter, Z 2011. Displacement of crime and diffusion of crime control benefits in large-scale geographic areas, Campbell Database Systematic Reviews, The Campbell Collaboration, Oslo. Available at: campbellcollaboration.org/library.php. 
This text is taken from Regulatory Theory: Foundations and applications, edited by Peter Drahos, published 2017 by ANU Press, The Australian National University, Canberra, Australia. 